Colloquia Litteraria

UKSW

$1 / 2017$

MAGDALENA WOŹNIEWSKA-DZIAŁAK

\title{
ONTYCZNOŚĆ NARODU W MYŚLI CYPRIANA NORWIDA
}

Naród to jedno z najważniejszych zagadnień w twórczości Norwida. Uczynił je poeta tematem wiodącym poematów dyskursywnych z końca lat czterdziestych, takich jak Pieśni społecznej cztery stron czy Niewola, nie pominął go również w poemacie o sztuce z roku 1850, w przełomowym dla jego własnej biografii twórczej Promethidionie, nie zaniechał w wykładach O Juliuszu Słowackim... z końca lat sześćdziesiątych czy w Rzeczy o wolności słowa, ostatnim dziele, które zdołał upublicznić autorskim odczytem. Równie interesująco wyłożył swą koncepcję narodu w pismach o charakterze publicystycznym, takich jak: Głos niedawno do wychodźtwa polskiego przybyłego artysty, Listy o Emigracji, czy mniej znanych: Noty o konieczności presji moralnej, Odpowiedź Cypriana Kamila N. niektórym obywatelom o stanie rzeczy narodowej zapytujacym, wreszcie Znicestwienie narodu.

Słusznie określano Norwida historiozofem narodu; dysponując głębokim zmysłem dziejowości i świadomością rdzennie historyczną - co dostrzegł trafnie już Stanisław Brzozowski ${ }^{1}$, a w znakomitym szkicu o Norwidzie wyeksponował Bogusław Dopart ${ }^{2}$ - poeta rozumiał wiek XIX inaczej niż poprzednicy, przypatrywał mu się

\footnotetext{
1 Zob. Stanisław Brzozowski, Testament Cypriana Norwida, w: tegoż, Kultura iżycie. Zagadnienia sztuki i twórczości. W walce o światopoglą, wstępem poprzedził Andrzej Walicki, Warszawa 1973, s. 217-224; Zob. też Stanisław Brzozowski, Legenda Młodej Polski. Studia o strukturze duszy kulturalnej. 1, Kraków 2001.

${ }_{2}$ Zob. Bogusław Dopart, Norwida sprawa o Polske, w: Historia ma konsekwencje. Mickiewicz, Mochnacki, Norwid, Witkacy o dziejach Polski, pod red. Arkadego Rzegockiego, Kraków-Warszawa 2012, s. 55.
} 
z szerszej, nieznanej im perspektywy. Nieznanej, bo uwzględniającej dziejową zawieruchę - wraz z dwoma dziewiętnastowiecznymi insurekcjami, wraz z doświadczeniem Wiosny Ludów i wszystkim tym, co zadecydowało o losach ojczyzny $\mathrm{w}$ drugiej połowie rzeczonego stulecia. Jego uprzywilejowana sytuacja wynikała także i stąd, że namysł nad dziewiętnastowiecznym historyzmem wiódł jako człowiek dorosły i doświadczony, ten, który przeżył Mickiewicza, Słowackiego, Krasińskiego o prawie trzydzieści lat, ten, którego nazwisko chce być przez wielu kojarzone z nową epoką. Badania Andrzeja Walickiego ${ }^{3}$ (mające najszerszy rezonans w literaturze przedmiotu), Elżbiety Feliksiak $^{4}$ czy Marcina Króla ${ }^{5}$ pokazują, jak złożony jest problem ontyczności narodu (sposobu jego istnienia) w myśli Norwida. Akcentowane w przywołanych pracach antymesjanizm i antymillenaryzm autora Quidama, rozumiane jako opozycja wobec poglądów Mickiewicza i Cieszkowskiego, sprowokowana w dużej mierze wydarzeniami rzymskimi z roku 1848, w żadnej mierze nie wyczerpują wskazanego zagadnienia. Koncepcja procesu dziejowego, myśl o Boskiej Opatrzności - czuwającej nad losem narodów i od zawsze w historii obecnej, dualizm duchowo-cielesny człowieka i dualizm narodu; Norwidowski podział na lud i społeczeństwo, zadania $\mathrm{z}$ owego podziału wynikające; kwestia języka narodowego i narodowej sztuki (zwłaszcza w odniesieniu do Promethidiona), w końcu krytyczna wobec działań emigracji postawa poety oraz surowa ocena sposobów gospodaro-

\footnotetext{
3 Andrzej Walicki, Cyprian Norwid. Trzy wątki myśli, w: tegoż, Między filozofia, religia i polityka. Studia o myśli polskiej epoki romantyzmu, Warszawa 1983.

${ }^{4}$ Elżbieta Feliksiak, Poezja i myśl. Studia o Norwidzie, Lublin 2001.

${ }_{5}$ Marcin Król, Konserwatyści a niepodległość. Studia nad polska myśla konserwatywna XIX wieku, Warszawa 1985.

"W Listach o Emigracji Norwid pisze: „Przedwieczny wszędzie jest - dlaczegóż nie miałby być w historii? Owóż jest On w historii przez człowieka, tak jak w historii każdego człowieka jest przez siebie, przez Boga-człowieka - przez Chrystusa" (PWsz VII, 28). Cytaty z tekstów Norwida wg edycji: Cyprian Norwid, Pisma wszystkie, zebrał, tekst ustalił, wstępem i uwagami krytycznymi opatrzył Juliusz W. Gomulicki, t. I-XI, Warszawa 1971-1976; dalej: PWsz, liczba rzymska oznacza numer tomu, arabska - strony.
} 
wania „stanem narodowej rzeczy” dopełniają szerokiego spektrum problemów skoncentrowanych wokół interesującego nas tutaj tematu. Czy można i czy w ogóle należy rozważać od podstaw i od początku Norwidowską ontyczność narodu, w którą wszystkie wymienione zagadnienia, dostrzeżone już i komentowane, wpisują się niemalże równoważnie? Ze względu na dzisiejsze kryteria czytania Norwida i na to, że dziś inaczej postrzegamy relację pomiędzy tekstami poetyckimi a publicystycznymi poety (wskazując ich „zażyłą" więź), odpowiedź musi być chyba twierdząca. Należałoby zacząć więc od pytania: jaka mogłaby być ontologia narodu w tej fazie romantyzmu polskiego, gdy Norwid buduje swój świat myśli i jeszcze modyfikuje swoje idee $\mathrm{w}$ dialogu $\mathrm{z}$ wieszczami i myślicielami, tworzącymi jego bliskie otoczenie i niejednokrotnie pozostającymi z poetą $\mathrm{w}$ przyjacielskich stosunkach? Jak możliwe jest owo poszukiwanie własnej koncepcji w atmosferze poczucia przełomowości epoki ${ }^{7}$ i wielości popularnych, funkcjonujących już ideologii? Spróbujmy przyjrzeć się tej sytuacji ze stanowiska obserwacyjnego samego Norwida. Otóż w latach czterdziestych, gdy proces budowania świata myśli poety jest najbardziej dynamiczny, istnieją dla niego w zasadzie dwie, trzy drogi, uprzywilejowane możliwości, z których może skorzystać. Po pierwsze filozofia ducha narodowego, taka, jaką najpierw uprawiał Maurycy Mochnacki, a później August Cieszkowski i filozofia krajowa ${ }^{8}$. Po drugie zaś mesjanizm, który rodzi się w poezjach Mickiewicza i szerzej nieznanej filozofii Hoene-Wrońskiego; mesjanizm, ulegający ufilozoficznieniu w Prelekcjach paryskich, w których zresztą Mickiewicz już bilansuje jego dokonania. Myśl Zygmunta Krasińskiego, który łączy obie te tradycje i odciska swoje indywidualne piętno na ich losach, również stanowi jeden $\mathrm{z}$ wariantów czy też jedną z opcji światopoglądowych młodego Norwida.

\footnotetext{
7 Zob. Andrzej Walicki, dz.cyt., s. 97.

${ }^{8}$ Norwid poznaje Augusta Cieszkowskiego bardzo wcześnie, jeszcze w Warszawie, przed opuszczeniem ojczyzny na stałe. Ich znajomość trwa długo, do śmierci poety w 1883 roku.
} 
Czy Norwid wstępujący na scenę obywatelską wśród emigracji jest kontynuatorem którejś z tych koncepcji, czy też, opowiadając się wobec nich, od razu zajmuje stanowisko - przynajmniej w pewnej mierze - samodzielne? Już w pierwszym ważnym wystąpieniu, w Brukseli w 1846 roku, Norwid podejmuje problematykę romantycznej spekulacji oraz proklamacji mesjanicznej. Wchodzi z romantykami w dialog, włącza się w romantyczny dyskurs o historii jako żywo zainteresowany losami narodu obywatel i gorliwy patriota. W Głosie niedawno do wychodźtwa polskiego przybyłego artysty, doskonale wyczuwając nastroje słuchaczy, mówi:

Było życzeniem zgromadzonych, ażebym dziś przemówił - czymże jednak potrafię to zawdzięczyć, jeśli nie p r a w d ą i wspomnieniem o narodowych rzeczach, czymże uczcić potrafię dzień dzisiejszy w drobnej mojej cząsteczce? Dzień, który jest rocznicą odezwania się wszystkich sił narodu przeciw mocom n i e praw d y...

[...] Wy to czujecie w drżeniu nici od ran Waszych idącej do oddalonych mogił Polski, jak pocieszającym i jak trudnym jest odsłonięcie prawdy onej, za którą jedni na wygnaniu, drudzy cierpią w więzieniach - a inni... więcej już nie cierpią... [PWsz VII, 7]

Poeta oddaje cześć polskiemu narodowi, wyraża swój głęboki szacunek wobec „arcydrogiej chwili” - męczeńskiej karty jego historii. (Nie zapominajmy, że przemawia z okazji szesnastej rocznicy wybuchu powstania listopadowego). Wierzy w naród silny, który trwa i który podnosi się z upadku, ale jednocześnie w cierpieniu, ofierze, w tej narodowej pasji nie spodziewa się on eschatologicznego cudu, ponieważ uznaje za porządkujący i nadrzędny pewien moralny ład, mający uniwersalny, chrześcijański charakter. W tym samym tekście czytamy:

[...] N a r ó d - Ziomkowie! - jest to najstarszy po Kościele obywatel na świecie: ramiona jego kolosalne jako dęby litewskie, a czoło jego w chmurze ognia - wszystkie dziadów pancerze są jako łuszczki zbroi jego, tak szerokie ma piersi!... A każde prawe serce polskie jest jednym pulsu uderzeniem tej zbiorowej osoby. Głosem tego Narodu jest 
h a r m o n i a ojczysta, mieczem - jedność i zgoda, celem - p r a w d a. On idzie przez krew, popiół, przez rozczarowanie i przez słow oprzez milczenie pokory i to, co D z i s i a j nazywa. [...]

Bo Ojczyzna [...] jest to moralne zjednoczenie [...] [PWsz VII, 7-8]

Naród jest „zbiorową osobą”, której puls wyznacza prawość ludzkich serc. Wszyscy, którzy ów zbiorowy byt tworzą, są odpowiedzialni za jego „przytomne istnienie”. Jego głosem nie jest szczęk oręża, lecz jedność i zgoda, milczenie i pokora, celem - prawda.

Zauważmy: już tutaj - w tym wczesnym tekście z 1846 roku - pojawia się sugestia, że istoty narodu jako zbiorowego bytu poszukiwać należy we wzajemnym zobowiązaniu tych, którzy go tworzą, tych, którzy czynią z niego żywy, pulsujący organizm. Wydaje się, że poeta uzależnia kondycję narodu (narodu jako realnego bytu) od kondycji jednostek, ich intelektualnych i moralnych „zdolności”, i rezygnuje ze spekulacji historiozoficznej, jaką oferuje filozofia narodowa, zdominowana i zdeterminowana osiągnięciem różnorako - odmiennie niż tutaj - rozumianego celu (jako ostatni etap dziejów, epoka duchów, czynu, epoka przebóstwienia, ofiary itp.). Norwid idzie raczej $\mathrm{w}$ kierunku ujmowania istoty bytu narodowego w kategoriach etosowych. Co to znaczy? Otóż, w moim przekonaniu, duch narodowy konstytuowany jest tu przez wartości, a nie przez dynamizm idei czy dynamizm spirytualny zyskujący sens ze względu na pewien cel. Słusznie zauważył Marcin Król, diagnozując wskazywany tu problem, że w Norwidowskiej koncepcji tkwi przekonanie, iz „w historii nic się nie potwierdza, natomiast $\mathrm{w}$ historii w wyniku wytężonej pracy wielu pokoleń powstaje taka rzeczywistość, w której w coraz większym stopniu wypełniane są wartości"9. Norwid daje nam do zrozumienia, że ducha narodowego poznajemy poprzez etos, a etos jawi się poprzez krzyż, cierpienie i służbę. Cierpienie nie dla samego cierpienia, służbę nie dla poniżenia, lecz dla wypełnienia ziemskiej, doczesnej misji, jaką jest życie podług ewangelicznych wskazówek.

Przed Promethidionem odbijają się w pismach Norwida rozmaite inspiracje. W Listach o Emigracji z 1849 roku Norwid wyznaje:

\footnotetext{
9 Marcin Król, dz.cyt., s. 163.
} 
„Z głęboką pokorą utrzymuję, że naród polski Chrystusowej męki wypełnia podobieństwo" (PWsz VII, 22), ale zaraz objaśnia, że nie powinniśmy czuć się zwolnieni z konkretnych zadań do wykonania, $\mathrm{z}$,dobrego czynienia”, z pokory wobec faktów historii. Oczekiwanie na jakieś fatum, na jakieś „tragiczne spełnienie” inne niż to, o którym mowa w wersetach Apokalipsy, jest nieuzasadnione. „F a t u m to ni e Chrystus" - kwituje w puencie przywołanych Listów... (PWsz VII, 28), wskazując na twarde chrześcijańskie podłoże swej wyobraźni, odległe od profetycznego patosu romantyków. Norwida nie interesują warianty nowej, apokryficznej Ewangelii. Dlatego wobec filozofii narodowej pozostaje z pewnym dystansem, a w jego koncepcji dominujące jest myślenie w kategoriach etosowo artykułowanego ducha narodowego. Najbliżej Norwidowi chyba do Karola Libelta jako autora rozprawy $O$ miłości ojczyzny, wydanej w 1844 roku, później kilkakrotnie wznawianej. Filozof pisze w niej o żywocie politycznym i żywocie moralnym narodu, o posłannictwie, o doskonaleniu się w działaniu na jego korzyść i dla jego uświęcenia i o tym, co Norwida żywo obchodzić musiało - o miłości ojczyzny udowadnianej czynami, nie tylko z uczuć wypływającymi, lecz i tymi, które podług "przewodniej gwiazdy rozumu” są przedsiębrane ${ }^{10}$.

Norwidowe poglądy nie wykluczają opcji organicystycznej. Poeta jest przekonany o tym, że Boski ład opatrznościowy jest czynnikiem organizującym życie narodu, ramą tego życia. Z tego powodu, że niezbędna jest organiczna ciągłość i przestrzeganie ładu opatrznościowego, wszelkie działania muszą być stosowne względem czasu i sytuacji. Inaczej skazane są na niewczesność. Niewczesność zaś oznacza porażkę, upadek, klęskę, niemożność zrealizowania. W poemacie Z 1850 roku zamknie poeta tę myśl w formule „uniepotrzebniania męczeństwa" i nada jej miano tej, od której zawisły jest cywilizacyjny postęp.

${ }^{10}$ Karol Libelt, O miłości ojczyzny, w: tegoż, Samowładztwo rozumu i Objawy filozofii słowiańskiej. O miłości ojczyzny. System umnictwa. O panteizmie w filozofii, oprac. i wstępem opatrzył Andrzej Walicki, Warszawa 1967, s. 38. 
„Moralne zjednoczenie”, „naród jako prosty człowiek, który dogrzebuje się pierwotnych wartości pracą i modlitwą”, „naród, którego ramiona jako dęby, a czoło w chmurze ognia”, „harmonia ojczysta jako głos narodu", to motywy - wskazówki dla dalszego etapu myśli poety, którego wykładnią jest Promethidion. To w tym poemacie Norwid mówi:

Odkupywać ciężar pracy m i ło ści ą t wó r c z ą - to jest raczej do czynienia stojącemu w prawdzie obowiązku-mnożyć ch l e b y cudem patriotyzmu dodatniego, twórczego... cudem, mówię, m i ł ości tego o b o wi ą z k u, który-to Ojczyzną albo narodem nazywamy. [PWsz III, 469]

Ojczyzna to przede wszystkim zbiorowy obowiązek. To zadanie historyczne - zadanie do wypełnienia, wynikające z obiektywnych warunków procesu historycznego, w którym przeszłość, teraźniejszość i przyszłość mają taką samą wartość.

Pomiędzy przes złości ą a przys złości ą otwiera się próżnia rozpaczliwa... w tej próżni zrodzone pokolenie - między p r z eszłością a przyszłością nie złączonymi niczym... czymże w rzeczywistości ma pozostać?... aniołem, co przelata - upiorem, co przewiewa - zniewieściałym n i c z y m... męczennikiem... Hamletem... [PWsz III, 466]

W Memoriale o Młodej Emigracji z 1850 roku poeta uznał za konieczne powtórzyć, że:

[...] Ojczyzna jest to wielki-zbiorow y-Obowiązek, un devoir collectif...

Że Obywatele Ojczyznę składający dzielą się samą naturą rzeczy bez żadnego prawa nałożonego z góry (bo tego być nie może) - na: (1) służących Ojczyźnie przez siebie, przez człowieka swojego... 
i (2) na służących człowiekowi przez Ojczyznę, bo taki organizm w naturze rzeczy jest - i nie są to kasty - ani stopnie sztuczne - ale prawo wrodzone - natura-rerum. [PWsz VIII, 109]

Norwid wyraźnie dystansuje się wobec romantycznej historiozofii (filozofii spekulatywnej) na rzecz czynnika wolicjonalno-powinnościowego. Chce, aby zrozumiano, że wspólny wysiłek, trud, tu i teraz to owo symboliczne zdobywanie "prac ludzkich wieży”, że to właściwy cel zmagań z czasem, sobą samym, z historią i epoką. Poczuć odpowiedzialność, doświadczyć odpowiedzialności, pojąć własną misję jako cząstkę misji ogółu, misji miłości i doskonalenia - oto Norwidowska koncepcja „istoty” narodu, realizującego się poprzez służbę i oddanie w wypełnianiu „obowiązku obowiązków”. Warto i tu wskazać na Libelta, którego rozprawa, jak sądzę, mogła mieć na Norwida znaczący (dotąd nie zbadany) wpływ. Libelt pisał:

Uczciwość i życie nieposzlakowane ma być zaletą człowieka i z tego przymiotu szanowanym każdy do jakiegokolwiek stanu należy [...] Nareszcie zdatności pracą nabyte, poświęcenia spełnione niech będą miarą zasług obywatelskich, miarą szacunku i poszanowania współobywateli [...] schyl czoło przed zasługą, bo w zasłudze jest obecny duch Boży i błogosławieństwo jego na cię zstąpi ${ }^{11}$.

Norwidowski humanizm, prezentowany zwłaszcza w odezwach i memoriałach $z$ lat okołopowstaniowych, w których perspektywa powinności narodu i służby zostaje wyłożona szczegółowo poprzez podejmowane w publicystyce tych lat problemy, wydaje się naturalną konsekwencją przekonania o randze służby i poświęcenia. Norwid apeluje na przykład o zaniechanie kary cielesnej, jest postulatorem „stosownego wymiaru sprawiedliwości” (Nota [w sprawie kary cieles$n e j]$ ), apeluje o podjęcie narodowego postu, rozważając przy tym także ekonomiczny zysk, który można byłoby wykorzystać, dopomagając w biedzie potrzebującym ([Głos w sprawie postu narodowego]), agituje w sprawie presji moralnej, która winna stanowić wariant współczesnej walki duchowej i która winna być cechą charakterystyczną polskiej

${ }^{11}$ Karol Libelt, dz.cyt. , s. 23. 
inteligencji, podejmującej działania umacniające nie rosyjski, lecz - co oczywiste - polski patriotyzm. ([Noty o konieczności presji moralnej]). Poszukuje Norwid rozwiązań i sposobów, którymi bez krwawych przewrotów i nieprzemyślanych, przedwczesnych czynów można byłoby wypełniać zadane powinności.

Zauważmy jednak, że Norwidowe myślenie o narodzie zmienia się, a owa zmiana wiąże się z perspektywą rozwijania krytycznej analizy skutków zachowań czy to polityczno-militarnych, czy to cywilizacyjnych, podejmowanych dla rozwoju i utrzymania bytu narodowego. To ona redefiniuje rozumienie ontyczności narodu w myśli Norwida. Andrzej Walicki zauważył, że zmiana statusu narodu w światopoglądzie Norwida była między innymi reakcją na narodową klęskę i na zasadniczą zmianę międzynarodowego statusu sprawy polskiej ${ }^{12}$. I mimo że poeta $\mathrm{z}$ ekscytacją komentuje bieżące wypadki w okresie okołopowstaniowym, mimo że nie jest w stanie zachować wówczas właściwego sobie dystansu i powściągliwości, zmienia retorykę swych wypowiedzi. Mówi o sobie „obywatel Rzymu”, w Mojej ojczyźnie wyznaje: „Naród mię żaden nie zbawił ni stworzył” (PWsz I, 336, w. 13). Z biegiem siódmej dekady wieku XIX - jak podkreśla autor szkicu Cypriana Norwida sprawa o Polskę - pisarz dostrzega, że polskie życie zbiorowe ulega decentralizacji i fragmentaryzacji, że pozbawione zostaje wyraźnego podmiotu władczego, „sensu pospolitej rzeczy” i pojęcia władzy prawowitej ${ }^{13}$. W ważnym traktacie [Znicestwienie narodu], powstałym jako konsekwencja rozważań z Filozofi historii polskiej, Norwid operuje nową terminologią. Pisze o narodzie w innych kategoriach, chce widzieć w nim „syntetyczną całość”, coś, co rodzi się z miłości i dla miłości istnieje. Twierdzi, że to ona - miłość uzdalnia go do zmian, do działania, odrodzenia. Ale znicestwienie nazywa realną konsekwencją pogrążania się w „zbłądzeniu”. Naród, który błądzi, który przyzwala, aby zło przeniknęło wszystkie obszary ludzkiej działalności, skazany jest na porażkę. Pisze, że jeżeli naród uwielbi:

12 Andrzej Walicki, Filozofia polskiego romantyzmu, Kraków 2009, s. 489.

13 Bogusław Dopart, dz.cyt., s. 86. 
w sobie to zbłądzenie, utracając przez nie spółczesność, [...] cokolwiek bądź poczynać będzie, wszystko nie na czasie zagai się, ale zawsze zbyt wcześnie lub za późno. [PWsz VII, 87)

Poeta formułuje w [Znicestwieniu narodu] ważny postulat odbudowania go „od gruntu”, nie od początku, nie „od niczego” rozpoczynając, ale od momentu, w którym harmonia wielu pierwiastków narodowej całości była jeszcze czytelna. Ostrożnie, i mając na uwadze ryzyko „powaśnienia narodu z własną przeszłością i tradycją”, sugeruje, że można powoli dążyć do odrodzenia. Ale czy ono nastąpi? Odrodzenie nie jest sprawą prostą, gdy nihilizm dławi każdą przedsiębraną racjonalnie inicjatywę. W szkicu [Nihilizm i nihiliści] z 1879 roku czytamy:

Mnie się zdawało było, iż Polska u p r z e d z a ją c tę powódź z g ó r y wyrzeczonym manifestem swoim narodowym, była mogła coś więcej historycznego względem siebie począć, aniżeli być objętą z dołu prądami nieuniknionego i szerokiego biegu rzeczy. [PWsz VII, 104]

Podobny charakter mają listy poety $\mathrm{z}$ lat siedemdziesiątych i osiemdziesiątych. Na przykład w liście do Leonarda Niedźwieckiego Z 1882 roku Norwid ubolewa:

[...] rozlał się szeroko polski $\mathrm{n}$ i h i l i z m. Polski nihi[liz]m gorszy od ruskiego, bo ten paląc i mordując jużci w coś na przyszłość wierzy - ale polski jest zupełnie co innego - zasadą jego jest: s p ro wadzić wszystko do własnej niziny prywatnej i myśleć, że to do wysokości morza. [PWszX, 182]

W późnej refleksji Norwida nasilają się obawy, że trwanie narodu w stanie, który poeta diagnozuje jako stan rozkładu, będzie na dobrą sprawę, w dłuższej perspektywie, bardzo trudne, a może nawet niemożliwe.

Czy Norwid próbuje ocalić jakiś eidos narodu? Czy szuka nadziei w wizji narodu jako wiecznej idei? Raczej dochodzi do kresu wszelkich złudzeń odnośnie do niezależnej od wspólnotowej woli podmiotowości tego bytu. Norwidowy zakład albo-albo jest bardzo konkretny. Albo Polacy odtworzą naród dojrzały, który ma dostateczne 
kompetencje społeczne i przede wszystkim siłę woli, aby kontynuować swe istnienie, albo też znicestwienie narodu, o którym była mowa, stanie się hipotezą bardzo prawdopodobną, w każdym razie taką, której na pewno nie da się wykluczyć.

\section{Summary \\ Onticism of the nation in Cyprian Norwid's thought}

The article originates from a larger scale study dealing with the Polish nation and identity in Norwid's writings. The author exposes the poet's attention to the philosophy of history and underscores the constant presence of threads linking the Polish affairs with the history of the humankind in Norwid's poetic and journalistic works. This piece argues that Norwid in his reflection on the nation assumes understanding of the essence of the nation's being in categories of ethos.

Magdalena Woźniewska-Działak (Uniwersytet Kardynała Stefana Wyszyńskiego) - dr, adiunkt w Katedrze Teorii Kultury i Międzykulturowości na Wydziale Nauk Humanistycznych UKSW. Autorka monografii Poematy narracyjne Cypriana Norwida. Konteksty literacko-kulturalne, estetyka, myśl, Kraków 2014. 